Research Article

\title{
Effect of nimodipine and flunarizine on neuromuscular function in mice
}

\author{
Swapnil B. Kaikade*, Nitin D. Pise
}

\begin{abstract}
Department of Pharmacology, ACPM Medical College, Dhule, Maharashtra, India
\end{abstract}

Received: 27 May 2016

Accepted: 01 July 2016

\section{*Correspondence to:}

Dr. Swapnil B. Kaikade, Email: skaikade@ rediffmail.com

Copyright: (C) the author(s), publisher and licensee Medip Academy. This is an openaccess article distributed under the terms of the Creative Commons Attribution NonCommercial License, which permits unrestricted noncommercial use, distribution, and reproduction in any medium, provided the original work is properly cited.

\begin{abstract}
Background: Changes in the intracellular concentration of $\mathrm{Ca}^{2+}$ control a number of cellular and physiological processes, hormone secretion, and cell fate and gene expression. The objective of this study was to study the effect of Ltype of calcium channel blocker nimodipine and T-type of calcium channel blocker funarizine on neuromuscular function in mice without pre-treatment by any other drug.

Methods: The study was carried out following permission from the Institutional animal ethics committee. Healthy Swiss albino mice of either sex were selected by the strict inclusion and exclusion criteria and the grouping is done. Group A is control treated with normal saline; group $\mathrm{B}$ and $\mathrm{C}$ received two titrated doses of nimodipine while group $\mathrm{D}$ and $\mathrm{E}$ received two titrated doses of flunarizine. The animals were then observed for neuromuscular function and the Statistical analysis was done by using unpaired ' $t$ ' test.

Results: L-type calcium channel blocker nimodipine has dose dependent effect on locomotor activity on traction wire and while the T- type calcium channel blocker flunarizine has no effect on locomotor activity.

Conclusions: Nimodipine has significant dose dependent depressant action on neuromuscular function while flunarizine has no effect on the above mentioned parameter.
\end{abstract}

Keywords: Nimodipine, Flunarizine, locomotor activity

\section{INTRODUCTION}

Changes in the intracellular concentration of $\mathrm{Ca}^{2+}$ control a number of cellular and physiological processes, hormone secretion, and cell fate and gene expression. As such, the control of the intracellular $\mathrm{Ca}^{2+}$ concentration is critical to the functioning and survival of the cell.

Calcium $\left(\mathrm{Ca}^{2+}\right)$ plays an important physiological role in the functions of excitable and non-excitable cells. It has also been reported that neurotransmitter release is a calcium dependent process and $\mathrm{Ca}^{2+}$ influx into the presynaptic terminal of the nerve via voltage-activated $\mathrm{Ca}^{2+}$ channels (VACC) is essential for neurotransmitter release. $^{1-2}$
It has been reported that L-type $\mathrm{Ca}^{2+}$ channels are also present in NMJs and contribute to neurotransmitter release. $^{3}$

Calcium ions play an essential role in regulating skeletal and smooth muscle contractility. Pathological changes in calcium channel expression have been shown to occur in several disease states including neuropathic pain, epilepsy and congestive cardiac failure.

Calcium channel blockers are one of the most important pharmacological advances of this decade. It was found that only L-type channels were sensitive to calcium channel-inhibiting drugs. Drug sensitivity of different tissues is different as the distribution of channel subtypes differs in various tissues. In addition, even the L-type 
calcium channels are different in various tissues with respect to their affinities for calcium antagonists. ${ }^{4}$

The use of drugs targeting calcium channels now extends far beyond the original discoveries of fleckenstein. ${ }^{5}$

Nimodipine has been approved for use in patients with neurological deficits.

The effects of one calcium antagonist should not be extrapolated to another of a different subtype because drugs belonging to different subtypes have different pharmacological effects. ${ }^{6}$

Keeping in view the entire saga of chronological development of calcium channel blockers, the present study was conceived, designed and carried out to study the effect of nimodipine and flunarizine on neuromuscular function in mice.

The objective of this study was to study the effect of calcium channel blockers on locomotor activity in mice. And to study the effect of L-type of calcium channel blockers nimodipine and t-type calcium channel blocker fluarizine on neuromuscular function in mice without pre-treatment by any other drug.

\section{METHODS}

The study was carried out at research laboratory, department of pharmacology, Jawaharlal Nehru Medical College, Sawangi (Meghe), Wardha. Between $1^{\text {st }}$ January 2010 to $30^{\text {th }}$ June 2011. The research protocol was submitted to the secretary, institutional animal ethics committee, Jawaharlal Nehru medical college, Sawangi (Meghe), Wardha, on 06.08.2009, for approval. The research protocol was approved by I. A. E. C. in the meeting held on 23.12.2009.

Healthy Swiss albino mice of either sex weighing between 20-30 gms were selected and maintained in identical conditions. They were housed in colony cages with free access to food and water except just before and during experimentation. All the experiments were performed between 10 am to $4 \mathrm{pm}$ at room temperature in noiseless, well ventilated and illuminated room.

Table 1: Test samples.

\begin{tabular}{|llc|}
\hline Drugs & Manufacturer & Doses $(\mathrm{mg} / \mathrm{kg})$ \\
\hline Nimodipine & \multirow{2}{*}{ USV Ltd (Corvette) } & 3.9 \\
(Tab. Nimodip) & & 7.8 \\
\hline Flunarizine & \multirow{2}{*}{ Cipla Ltd, Mumbai } & 1.3 \\
(Powder) & & 2.6 \\
\hline
\end{tabular}

The drugs were dissolved in distilled water. The solutions were freshly prepared just before the experiments. All the drugs were injected orally. All aseptic precautions were taken while administering the drugs to the animals.
Equipment's for the study used traction wire apparatus.

\section{Acclimatization}

Animals were housed in polypropylene cages maintained at controlled temperature, light cycle and humidity. Animals were allowed to take rest for a period of one week, so that they were adapted to the new surrounding before experimentation. They were fed with the food provided by animal house and with water ad libitum.

\section{Inclusion criteria}

- Weight between 20 to 30 grams

- Healthy mice

\section{Exclusion criteria}

- Weight less than 20 grams or more than 30 grams

- Pregnant mice

- Diseased mice

- Newborn mice.

\section{RESULTS}

\section{Grouping of animals}

\section{Each group consisted 10 mice of either sex}

- Group A: control group, treated with normal saline

- Group B and group C: treated with nimodipine in 2 titrated doses respectively

- Group D and group E: treated with flunarizine in 2 titrated doses respectively.

\section{Traction wire test}

This test was performed to assess neuromuscular function. Mice were left to hang to a horizontal metallic wire, which they immediately grasp with the forepaws. The mouse was released to hang on with its forelimbs. The number of times animal fall down in 5 minutes was recorded.

Statistical analysis was done by using SPSS 17.0 version and results were analysed by using descriptive statistics and inferential statistics, using unpaired 't' test.

\section{Study of neuromuscular function}

Table 2: Effect of nimodipine on neuromuscular function on traction wire.

\begin{tabular}{|llll|}
\hline $\begin{array}{l}\text { Drug dose } \\
\text { (nimodipine) }\end{array}$ & \multicolumn{3}{c}{ Traction wire test (mean \pm SEM) } \\
\hline Control & $2.90 \pm 0.23$ & $2.90 \pm 0.23$ & $2.90 \pm 0.23$ \\
\hline $3.9 \mathrm{mg} / \mathrm{kg}$ & $4.50 \pm 0.42 *$ & $5.00 \pm 0.25 *$ & $9.10 \pm 0.62 *$ \\
\hline $7.8 \mathrm{mg} / \mathrm{kg}$ & $4.60 \pm 0.26 *$ & $4.20 \pm 0.41^{*}$ & $4.10 \pm 0.23 *$ \\
\hline *p $<0.05$ compared to control group.
\end{tabular}


Nimodipine had significant dose dependent depressant action on neuromuscular function on traction wire at both, $3.9 \mathrm{mg} / \mathrm{kg}$ and $7.8 \mathrm{mg} / \mathrm{kg}$ doses, at 15,30 and 45 minutes.

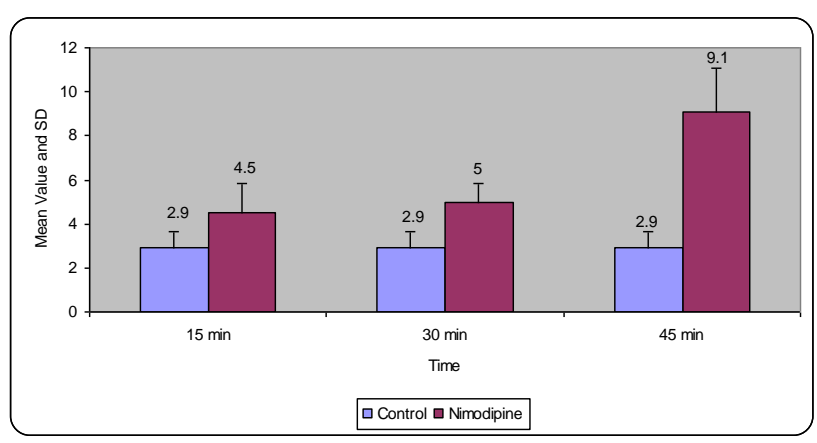

Figure 1: Effect of nimodipine $(3.9 \mathrm{mg} / \mathrm{kg})$ on neuromuscular function on traction wire.

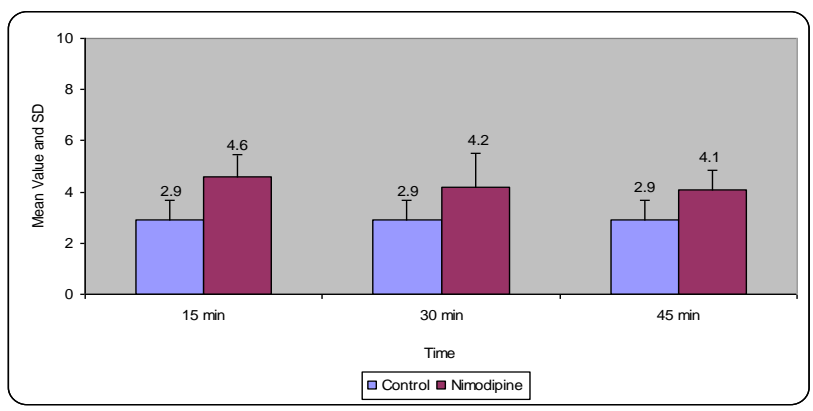

Figure 2: Effect of nimodipine $(7.8 \mathrm{mg} / \mathrm{kg})$ on neuromuscular function on traction wire.

Flunarizine did not produce any action on neuromuscular function on traction wire at both, $1.30 \mathrm{mg} / \mathrm{kg}$ and 2.60 $\mathrm{mg} / \mathrm{kg}$ doses, at 15, 30 and 45 minutes

Table 3: Effect of flunarizine on neuromuscular function on traction wire.

\begin{tabular}{|llll|}
\hline $\begin{array}{l}\text { Drug dose } \\
\text { (flunarizine) }\end{array}$ & \multicolumn{3}{l}{ Traction wire test (mean \pm SEM) } \\
\hline Control & $2.90 \pm 0.23$ & $2.90 \pm 0.23$ & $2.90 \pm 0.23$ \\
\hline $1.30 \mathrm{mg} / \mathrm{kg}$ & $2.80 \pm 0.24^{*}$ & $2.70 \pm 0.26^{*}$ & $3.10 \pm 0.27^{*}$ \\
\hline $2.60 \mathrm{mg} / \mathrm{kg}$ & $2.40 \pm 0.16^{*}$ & $2.60 \pm 0.22^{*}$ & $2.70 \pm 0.20^{*}$ \\
\hline
\end{tabular}

*p $>0.05$ compared to control group.

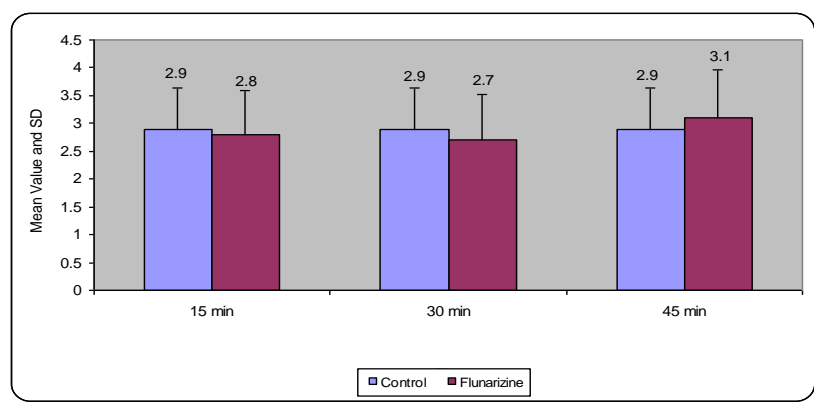

Figure 3: Effect of flunarizine $(1.30 \mathrm{mg} / \mathrm{kg})$ on neuromuscular function on traction wire.

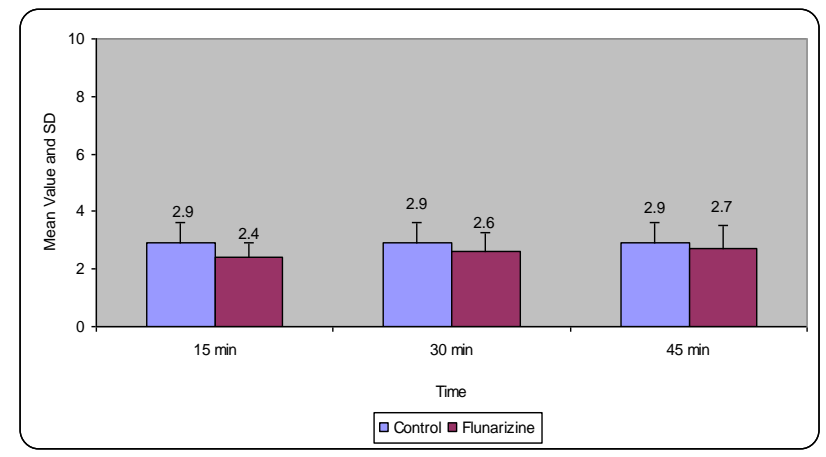

Figure 4: Effect of flunarizine $(2.60 \mathrm{mg} / \mathrm{kg})$ on neuromuscular function on traction wire.

\section{DISCUSSION}

Voltage-gated calcium channels play a major role in the normal functioning and also in various pathological processes that occur in neuronal, neurosecretory and muscle cells. $^{7}$

Altered balance between excitatory and inhibitory neuronal functions can result in various central nervous system diseases, including pain, epilepsy, seizure, anxiety, depression, dementia, and stroke . An efficient way of controlling such diseases is to block or modulate voltage dependent calcium channel (VDCC) function. ${ }^{8}$

Action potential in the nerve terminal results in calcium dependent release of dopamine. The extent of dopamine release appears to be function of rate and pattern of firing. The opening of calcium channel upon depolarization allows calcium to enter into presynaptic nerve terminal which results in increase in the calcium concentration inside the nerve terminal. Activation of calcium sensors leads to activation of fusion machinery in the nerve terminal. The main mode responsible for synaptic neurotransmission is quantal release. Activation of the fusion machinery causes the fusion of synaptic vesicles which stores the neurotransmitter with the surface membrane which leads to quantal release of dopamine. 9 Beninger RJ stated that changes in overall level activity of dopamine neurons appear to produce parallel changes in locomotor activity. ${ }^{10}$

\section{CONCLUSION}

On the basis of the present study, it has been concluded that L-type calcium channel blocker nimodipine has dose dependent effect on locomotor activity (neuromuscular function) in traction wire while T- type calcium channel blocker flunarizine has no effect on locomotor activity.

Funding: No funding sources

Conflict of interest: None declared

Ethical approval: The study was approved by the Institutional Ethics Committee 


\section{REFERENCES}

1. Mayor S. Diabetes affects nearly $6 \%$ of the world's adults. BMJ. 2006;333:1191.

2. King H, Aubert RE, Herman WH. Global burden of diabetes, 1995-2025: prevalence, numerical estimates and projections. Diabetes Care. 1998;21:1414-31.

3. Mohan V, Madan Z, Jha R, Deepa R, Pradeepa R. Diabetes-social and economic perspectives in the new millennium. Int $\mathrm{J}$ Diab Dev Countries. 2004;24:29-35.

4. Cantrill JA, Wood J. Diabetes mellitus. In: Walker $\mathrm{R}$, Edwards C, editors. Clinical pharmacology and therapeutic. $3^{\text {rd }}$ ed. New York: Churchill Livingstone; 2003;657-77.

5. The diabetes control and complications trial research group. The effect of intensive treatment of diabetes on the development and progression of long-term complications in insulin-dependent diabetes mellitus. N Engl J Med. 1993;329:977-86.

6. UK prospective diabetes study group. Intensive blood glucose control with sulphonylureas or insulin compared with conventional treatment and risk of complications in patients with type 2 diabetes (UKPDS 33). Lancet. 1998;352:837-53.
7. Bureau of national health insurance. Drug reimbursement price and date approved by bureau of national health insurance, 2007. Available at http://www.nhi.gov.tw/06inquire/query1.asp.

Accessed on 20 June 2007.

8. Powers AC. Diabetes mellitus. In: Braunwald E, Fauci AS, Kasper DL, Hauser SL, Longo DL, Jameson JL, editors. Harrison's principles of internal medicines. $15^{\text {th }}$ ed. New York: McGrawHill Inc; 2001:2109-37.

9. Triplitt CL, Reasner CA, Isley WL. Diabetes mellitus. In: Dipiro JT, Talbert RL, Yee GC, Matzke GR, Wells BG, Posey LM, editors. Pharmacotherapy: a pathological approach. $6^{\text {th }}$ ed. New York: McGraw-Hill Inc; 2005:1333.

10. Kennedy J, Erb C. Prescription noncompliance due to cost among adults with disabilities in the United States. Am J Public Health 2002;92:1120-4.

11. Bakssas I, Lunde PKM. National drug policies: the need for drug utilization studies. Trends Pharmacol Sci. 1986;7:331-4.

12. Press Trust of India. Insulin to cost less. The Hindu; 2003:13:(Col.1).

13. Boccuzzi SJ, Wogen J, Fox J, Sung JCY, Shah AB, Kim J. Utilization of oral hypoglycemic agents in a drug-insured US population. Diabetes Care. 2001;24:1411-5.

Cite this article as: Kaikade SB, Pise ND. Effect of nimodipine and flunarizine on neuromuscular function in mice. Int $\mathrm{J}$ Basic Clin Pharmacol 2016;5:1524-7. 